\title{
Evaluasi Proteksi Sabun Kalsium Sebagai Pakan Suplemen Berdasarkan Kecernaan Bahan Kering, Kecernaan Bahan Organik dan pH In Vitro di dalam Rumen dan Pasca Rumen
}

\author{
Pramono. $\mathrm{A}^{\mathrm{I}, \mathrm{III}}$, Kustono ${ }^{\mathrm{I}}$, D. T. Widayati ${ }^{\mathrm{I}}$, P. P. Putro ${ }^{\mathrm{II}}$, E. Handayanta ${ }^{\mathrm{III}}$ dan H. Hartadi ${ }^{\mathrm{I}}$

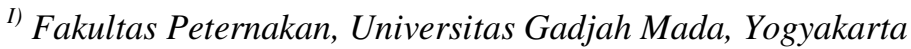

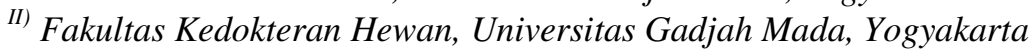

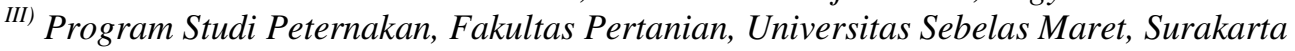 \\ Email:ahmad_pram@uns.ac.id
}

\begin{abstract}
ABSTRAK
Tujuan dari penelitian ini adalah untuk mengevaluasi proteksi sabun kalsium sebagai pakan suplemen berdasarkan kecernaan bahan kering $(\mathrm{KcBK})$, kecernaan bahan organik $(\mathrm{KcBO})$ dan $\mathrm{pH}$ secara in vitro di dalam rumen dan pasca rumen. Pakan suplemen sabun kalsium berbahan baku minyak ikan lemuru dan bungkil kedelai dibuat dengan metode proteksi penyabunan dan mikroenkapsulasi. Penelitian ini menggunakan rancangan Split Subject Repeated Measurement Design dengan 3 perlakuan (sabun kalsium, bungkil kedelai dan rumput pangola) masing-masing perlakuan diulang sebanyak 5 kali. Pengamatan kinetika $\mathrm{KcBK}, \mathrm{KcBO}$ dan $\mathrm{pH}$ rumen dilakukan pada titik inkubasi jam ke 2, 4, 8, 12, 24 dan 48 jam. Hasil penelitian tahap satu di dalam rumen menunjukkan bahwa sabun kalsium memiliki KcBK: 38,65 ; 40,00; 42,66; 46,32; 54,40 dan 51,40\%; KcBO: 39,44; 41,$27 ; 44,31 ; 46,32 ; 56,62$ dan 52,50\%. Kinetika pH cairan rumen masing-masing: 6,$89 ; 6,79 ; 6,78$; 6,$74 ; 6,71$; dan 6,88. Kecernaan bahan kering sabun kalsium pasca rumen 74,85\% dan kecernaan bahan organik $72,94 \%$. Hasil penelitian disimpulkan bahwa sabun kalsium paling tahan dari degradasi mikrobia di dalam rumen dibandingkan dengan perlakuan yang lain dan sabun kalsium dapat terdegradasi dan tercerna di dalam abomasum sampai dengan usus halus. Kondisi pH cairan rumen pada penelitian ini optimal sehingga tidak mengganggu fermentasi dalam rumen.
\end{abstract}

Kata kunci: sabun kalsium, in vitro, $\mathrm{KcBK}, \mathrm{KcBO}, \mathrm{pH}$

\section{Evaluation of Calcium Soap Protection as a Feed Supplement Based on Dry Matter Digestibility, Organic Matter Digestibility and $\mathrm{pH}$ in Vitro in the Rumen and Post Rumen}

\begin{abstract}
The research aims to evaluate calsium soap protection as feed supplement based on dry matter digestibility, organic matter digestibility and $\mathrm{pH}$ in vitro in the rumen and post rumen. Calsium soap was produced from sardine fish oil and soybean meal, through two protection methods. It was saponification and microencapsulation. This research used Split Subject Repeated Measurement Design with 3 treatments (calcium soap, soybean meal and pangola grass) which each treatment was repeated 5 times. The observation kinetics of dry matter digestibility, organic matter digestibility, and $\mathrm{pH}$ rumen fluid were done in incubation times $(2,4,8,12,24$ and 48 hours respectively). The first results of the research showed that in the first step (rumen) has dry matter digestibility of calcium soaps: $38.65 ; 40.00 ; 42.66 ; 46.32 ; 54.40$ and $51.40 \%$ respectively; organic matter digestibility: 39.44 ; $41.27 ; 44,31 ; 46.32 ; 56.62$ and $52.50 \%$ respectively. Kinetics of $\mathrm{pH}$ rumen fluid: $6.89 ; 6.79 ; 6.78$; $6.74 ; 6.71$, and 6.88 respectively. In the second step (post rumen), the digestibility of calsium soap production has dry matter digestibility of $74.85 \%$ and organic matter of digestibilty of $72.94 \%$. The results could be concluded that in the rumen, calcium soap is the most microbial degradation resistant compared the others and it can be degraded and digested in the abomasum to the small intestine. Therefore $\mathrm{pH}$ of rumen fluid is optimal, so it does not interfere with the fermentation in the rumen.
\end{abstract}

Keywords: calsium soap, in vitro, dry matter digestibily, organic matter digestibility, pH value 


\section{PENDAHULUAN}

Energi dan protein merupakan nutrien vital untuk semua ternak karena dibutuhkan untuk sintesis hormon, memperbaiki jaringan, sintesis susu dan fungsi fisiologis lainnya yang kesemuanya dibutuhkan guna memenuhi kebutuhan hidup pokok, pertumbuhan, produksi susu dan reproduksi (Lanyasunya et al., 2005). Peningkatan asupan energi pada ternak ruminansia dapat dilakukan dengan meningkatkan energi pakan menggunakan lemak (minyak), sedangkan asupan protein dapat ditingkatkan dengan pemberian protein terproteksi yang dapat lolos degradasi oleh mikrobia rumen (Pramono et al., 2011).

Kendala utama pemberian lemak yaitu lemak mudah mencair pada kondisi suhu rumen, sehingga dapat menghambat proses fermentasi bahan pakan dan aktivitas mikrobia dalam rumen. Salah satu sumber energi potensial, banyak tersedia, dan harganya murah adalah minyak ikan lemuru. Minyak ikan lemuru mengandung asam lemak tak jenuh tinggi. Suplementasi asam lemak tidak jenuh terbukti dapat meningkatkan efisiensi energi melalui peningkatan densitas energi dan menopang peningkatan efisiensi sintesis protein jaringan melalui peningkatan aliran nitrogen (N) non amonia ke duodenum (Elliot et al., 1997; Johnson et al., 2002). Kendala yang ditemukan apabila minyak ikan lemuru diberikan secara langsung dalam pakan adalah (1) adanya proses hidrogenasi dalam rumen yang mengubah lemak tak jenuh menjadi jenuh; (2) pemberian minyak dapat mengganggu aktivitas mikrobia selulitik, sehingga menurunkan laju fermentasi dalam rumen; (3) minyak ikan lemuru mempunyai bau (aroma) yang amis karena mengandung senyawa trimethil amin oksida yang apabila dicampurkan secara langsung dalam ransum, akan menyebabkan rendahnya palatabilitas sehingga sapi biasanya tidak mau makan (Pramono et al., 2011) .

Bungkil kedelai merupakan produk sampingan dari ekstraksi minyak dari kedelai utuh (Agus, 2012). Bungkil kedelai memiliki kelebihan yaitu kandungan protein yang cukup tinggi, nilai kecernaannya tinggi, baunya sedap, dan dapat meningkatkan palatabilitas ransum (Kamal, 1998). Namun pemberian bungkil kedelai tanpa proteksi pada sapi perah kecernaannya sangat tinggi dalam rumen sehingga protein tersebut akan dimanfaatkan oleh mikrobia rumen menjadi protein mikrobia.

Perlakuan proteksi dibutuhkan untuk memperoleh manfaat yang nyata dari adanya suplementasi sumber energi dan atau protein dalam pakan. Pada suplementasi asam lemak tidak jenuh proteksi diperlukan untuk menghindarkan asam lemak tidak jenuh dari biohidrogenasi ikatan ganda oleh mikrobia rumen (Ashes et al., 1995). Proteksi juga berguna untuk mengeliminasi dampak negatif suplementasi asam lemak tidak jenuh pada aras tinggi, berupa penurunan degradabilitas serat (Aharoni et al., 2004).

Metabolisme lemak pada sapi perah diupayakan by pass, karena profil asam lemak dalam jaringan adipose dapat mencerminkan profil asupan asam lemak asal pakan (Putro, 2007). Strategi untuk menurunkan kelarutan (pembentukan suspensi) asam lemak tak jenuh rantai panjang dalam rumen, adalah dengan diubah (dibuat) menjadi sabun kalsium (Jenskin dan Palmquist, 1984).

Sabun kalsium (Ca-soap) merupakan salah satu teknologi untuk melindungi lemak yang akhir-akhir ini banyak dikembangkan. Sabun kalsium merupakan bentuk lemak terlindung dan merupakan sumber lemak yang efektif dalam bahan pakan ternak ruminansia, karena sistem fermentasi rumen tetap normal, kecernaan asam lemaknya tinggi dan sabun ini dapat dengan mudah dicampur dengan beberapa jenis bahan pakan (Jenkins dan Palmquist, 1984).

Melalui metode saponifikasi dengan garam kalsium $\left(\mathrm{CaCl}_{2}\right)$ diharapkan penggunaan lemak pada taraf yang tinggi tidak menimbulkan dampak negatif terhadap ekosistem mikrobia rumen. Ikatan antara kalsium bersifat riversibel (dapat lepas kembali) pada kondisi asam. Sabun yang dihasilkan bersifat stabil (tidak mudah 
mencair atau terurai) dalam cairan rumen yang mempunyai $\mathrm{pH}$ netral, namun ikatan $\mathrm{Ca}$ dan asam lemak pada saat melewati abomasum yang mempunyai $\mathrm{pH}$ sangat asam akan lepas menghasilkan ion $\mathrm{Ca}$ dan asam lemak bebas dan selanjutnya masuk usus halus dan diserap pada usus halus. Pada saat masuk usus besar yang mempunyai $\mathrm{pH}$ netral sisa ion $\mathrm{Ca}$ dan asam lemak tidak membentuk sabun kembali (Schaefer, 2000). Percobaan pemberian lemak padat (tallow) asal hewan seperti minyak ikan yang dibuat sabun kalsium pada sapi terbukti dapat menurunkan degradasi lemak dari 52\% menjadi $44,9 \%$, dan pencernaan serat dalam rumen tetap normal (tidak ada gangguan) (Jenskin dan Palmquist, 1984). Penelitian ini bertujuan mengevaluasi proteksi sabun kalsium sebagai pakan suplemen berdasarkan kecernaan bahan kering $(\mathrm{KcBK})$, kecernaan bahan organik $(\mathrm{KcBO})$ dan $\mathrm{pH}$ secara in vitro di dalam rumen dan pasca rumen.

\section{MATERI DAN METODE}

Penelitian ini dilakukan di kandang percobaan Bagian Nutrisi dan Makanan Ternak, Laboratorium Ilmu Makanan Ternak, Laboratorium Teknologi Makanan Ternak Fakultas Peternakan Universitas Gadjah Mada dan Laboratorium Nutrisi dan Makanan Ternak Universitas Sebelas Maret.

\section{Materi penelitian}

Ternak yang digunakan pada penelitian ini adalah sapi Peranakan Ongole (PO) betina berfistula rumen sebanyak 2 ekor berumur sekitar tiga tahun, dengan berat badan $260 \mathrm{~kg}$ dan $325 \mathrm{~kg}$.

Bahan yang digunakan adalah minyak ikan lemuru dan bungkil kedelai sebagai bahan baku sabun kalsium. Komposisi asam lemak minyak ikan lemuru (MIL) tercantum dalam Tabel 1.

Pembuatan pakan suplemen sabun kalsium menggunakan metode penyabunan dan mikroenkapsulasi. Komposisi kimia sabun kalsium tercantum pada Tabel 2.

Bahan-bahan untuk analisis kecernaan in vitro seperti: gas $\mathrm{CO} 2$, cairan rumen, larutan McDougall (saliva buatan) termasuk larutan $\mathrm{CaCl}_{2} \quad 4 \%$ yang ditambahkan menjelang digunakan, $\mathrm{HCl}$ 20\%, dan pepsin 5\%. Peralatan yang digunakan adalah adalah timbangan analitik merk Sartorius dengan kapasitas 150 g, kain kasa, tabung reaksi $50 \mathrm{ml}$, karet penyumbat, waterbath, dispensette, jirigen, crucible, thermos, glasswool, gelas ukur $2000 \mathrm{ml}$, kompor listrik, pipet $5 \mathrm{ml}$, dan ballpump.

\section{Metode penelitian}

Dua ekor Sapi PO yang digunakan pada penelitian ini, ditimbang terlebih dahulu untuk mengetahui berat badannya sehingga dapat ditentukan kebutuhan pakannya. Kebutuhan bahan kering sapi per ekor menggunakan rumus kebutuhan bahan kering 3\% dari berat badan. Imbangan pakan hijauan : konsentrat adalah $70: 30$. Ransum yang digunakan mengandung protein kasar $12 \%$ dan total digestable nutrients $60 \%$. Bahan pakan yang digunakan untuk menyusun konsentrat terdiri atas konsentrat jadi nutrivit, branpollard, urea, dan mineral. Hijauan yang digunakan adalah rumput raja. Pakan diberikan dua kali sehari pada pukul 08.00 WIB dan 15.00 WIB, sedangkan air minum untuk ternak diberikan secara $a d$ libitum.

Sampel yang digunakan adalah pakan suplemen sabun kalsium, bungkil kedelai tanpa proteksi, dan rumput pangola. Kemudian sampel tersebut digiling menggunakan wiley mill dengan diameter lubang saringan ukuran $1 \mathrm{~mm}$.

Pengukuran kecernaan in vitro yang dilakukan mengacu pada prosedur Tilley dan Terry (1963) yang telah dimodifikasi oleh Utomo (2010), dimana terdapat perbedaan yakni pada prosedur tahap I ke tahap II tanpa adanya proses pencucian residu, sehingga langsung dilakukan penambahan $\mathrm{HCl}$ dan pepsin. Selain itu, pada prosedur Utomo (2010) materi, sampel, reagen dan volume 
Tabel 1. Hasil analisis komposisi asam lemak minyak ikan lemuru ${ }^{1}$

\begin{tabular}{lc}
\hline \hline \multicolumn{1}{c}{ Komposisi asam lemak } & Hasil analisa (\%) \\
\hline Asam Miristat & 13,515 \\
Asam Palmitat & 19,516 \\
Asam Palmitoleat & 13,530 \\
Asam Stearat & 3,053 \\
Asam Oleat (omega 9) & 10.896 \\
Asam Linoleat (omega 6) & 1,523 \\
Asam Linolenat (omega 3) & 0,411 \\
Asam Eikosapentaenoat (EPA) & 15,770 \\
Dokosaheksaenoat (DHA) & 6,672 \\
Asam Liknosenat & 0,282 \\
\hline
\end{tabular}

Hasil Analisis Laboratorium Bioteknologi, Fakultas TPHP UGM

Tabel 2. Komposisi kimia sabun kalsium minyak ikan lemuru dengan bungkil kedelai

\begin{tabular}{ccccccc}
\hline \hline \multirow{2}{*}{ Nama/kode sampel } & $\begin{array}{c}\text { Dasar } \\
\text { analisis }\end{array}$ & $\begin{array}{c}\text { PK } \\
(\%)\end{array}$ & $\begin{array}{c}\text { EE } \\
(\%)\end{array}$ & $\begin{array}{c}\text { SK } \\
(\%)\end{array}$ & $\begin{array}{c}\text { ABU } \\
(\%)\end{array}$ & $\begin{array}{c}\text { BK } \\
(\%)\end{array}$ \\
\hline Sabun Kalsium & DB & 17,30 & 23,15 & 0,19 & 18,67 & 89,79 \\
\hline
\end{tabular}

Hasil Analisis Laboratorium Nutrisi, Jurusan Perternakan, Fakultas Pertanian UNS

tabung reaksi yang digunakan adalah setengah dari prosedur Tilley dan Terry (1963).

Preparasi sampel yang digunakan ditimbang sebanyak $0,25 \mathrm{~g}$ menggunakan timbangan analitik, lalu dimasukkan ke dalam tabung reaksi $50 \mathrm{ml}$ dan diinkubasikan pada suhu $39^{\circ} \mathrm{C}$ selama semalam agar kondisinya sama seperti di dalam rumen. Pengambilan cairan rumen. Pengambilan dilakukan pada pagi hari sebelum ternak diberi pakan. Cairan rumen diambil dari sapi PO betina menggunakan aspirator, spite, dan thermos. Thermos sebelumnya diisi dengan air hangat (suhu $39^{\circ} \mathrm{C}$ ) sampai penuh, kemudian dibuang sebelum diisi dengan cairan rumen. Cairan rumen diambil dengan menggunakan aspirator, lalu dimasukkan ke dalam thermos sampai penuh untuk mencegah adanya oksigen. Kemudian cairan rumen dari thermos disaring dengan menggunakan kain kasa dan dimasukkan ke dalam erlenmeyer sambil dialiri gas $\mathrm{CO}_{2}$ dan diinkubasikan pada suhu $39^{\circ} \mathrm{C}$. Kemudian ditambahkan larutan McDougall (saliva buatan).

Sampel yang akan diuji dan telah digiling halus $1 \mathrm{~mm}$ kemudian ditimbang sebanyak $0,25 \mathrm{~g}$. Setelah itu dimasukkan ke dalam tabung reaksi volume $50 \mathrm{ml}$ dan selanjutnya diinkubasikan ke dalam waterbath dengan suhu $39^{\circ} \mathrm{C}$ selama 12 jam. Pada tahap satu, setelah 12 jam, tabung yang sudah berisi sampel tadi kemudian diisikan dengan campuran antara cairan rumen dengan larutan McDougall dengan perbandingan 1 cairan rumen : 4 larutan McDougall dan selanjutnya diinkubasikan lagi ke dalam waterbath. Titik-titik pengamatan sampel untuk perhitungan kecernaan bahan kering dan kecernaan bahan organik tahap pertama dilakukan pada inkubasi jam ke 2, 4, 8, 12, 24 dan 48. Tahap kedua untuk mengetahui kecernaan pasca rumen ialah dengan pemberian $\mathrm{HCl} 20 \%$ ke dalam tiap-tiap tabung reaksi sebanyak $3 \mathrm{ml}$ (dengan cara pemberian: 0,$5 ; 0,5 ; 1 ; 1 \mathrm{ml}$ ) dan setelah itu ditambahkan pepsin 5\% sebanyak $1 \mathrm{ml}$. Pada tahap kedua dilakukan pengamatan pada 48 jam kedua. Untuk setiap satu titik inkubasi dari perlakuan, blanko dan standar yang diinkubasikan dilakukan replikasi sebanyak 5 kali. Blanko adalah tabung yang diisi tanpa sampel perlakuan, fungsinya sebagai faktor koreksi. Standar adalah tabung yang diisi dengan 
rumput pangola. Penggojogan dilakukan secara manual setiap 8 jam sekali. Selanjutnya residu yang tersisa dalam tabung disaring dengan crucible yang telah diisi dengan glass wool yang sudah diketahui berat konstannya. Kemudian residu bersama glass wool dipanaskan dalam oven suhu $105^{\circ} \mathrm{C}$ selama 24 jam dan ditimbang, kemudian dilanjutkan kembali dengan proses pengabuan.

\section{Analisis data}

Data yang diperoleh dianalisis variansi menggunakan rancangan split subyek repeated measurement design (Astuti, 2007). Hasil pengamatan diuji menggunakan analisis varian. Perbedaan pengaruh perlakuan diuji menggunakan uji Duncan Multiple Range Test (DMRT).

\section{HASIL DAN PEMBAHASAN}

\section{Kecernaan bahan kering dan bahan organik tahap satu (rumen)}

Kecernaan in vitro merupakan salah satu metode untuk mengetahui persentase hilangnya kandungan nutrien bahan pakan selama proses fermentasi oleh mikrobia rumen yang disimulasikan di dalam rumen. Dengan diketahuinya kecernaan suatu bahan pakan, khususnya pada penelitian yang bertujuan untuk memproteksi asam lemak maupun protein pakan, maka nlai kecernaan ini menjadi penting untuk dapat digunakan sebagai parameter atau untuk mengetahui kestabilan produk bahan pakan tersebut di dalam rumen.

Hasil evaluasi kecernaan bahan kering sabun kalsium in vitro tahap 1 (rumen) disajikan pada Tabel 3. Sedangkan hasil evaluasi kecernaan bahan organik dapat dilihat pada Tabel 4.

Pada sistem pencernaan rumen (tahap 1 in vitro) dalam penelitian ini produk sabun kalsium berpengaruh sangat nyata $(\mathrm{P}<0,01)$ terhadap kecernaan bahan kering (KcBK) dan kecernaan bahan organik (KcBO). Nilai kecernaan bahan kering sabun kalsium tertinggi pada titik inkubasi 24 jam sebesar 54,40\% bila dibandingkan dengan kontrol yakni bungkil kedelai tanpa perlakuan proteksi $(84,60 \%)$ dan rumput pangola $(60,74 \%)$. Sedangkan untuk KcBO nilai terendah adalah sabun kalsium, bila dibandingkan dengan bungkil kedelai tanpa perlakuan proteksi $(85,82 \%)$ dan rumput pangola $(61,02 \%)$. Hal ini menunjukkan bahwa terdapat kemampuan perlindungan bahan pakan sabun kalsium terhadap kecernaan mikrobia di dalam rumen.

Produk sabun kalsium pada kecernan rumen (tahap 1) paling stabil/mempunyai kecernaan paling rendah. Hasil KcBO sabun kalsium di dalam pencernaan rumen pada penelitian ini lebih tinggi bila dibandingkan dengan penelitian Ueda et al., (2003) yakni sabun kalsium berbahan linseed oil dengan KcBO sebesar 43,4\% dan lebih rendah bila dibandingkan dengan penelitian Kowalski (1997), KcBO sabun kalsium berbahan baku minyak kanola 62,6\% dan KcBO kombinasi minyak kanola dengan bungkil kedelai sebesar $63,7 \%$. Hal ini dikarenakan sabun kalsium yang dihasilkan dari proses penyabunan pada campuran minyak ikan lemuru dan bungkil kedelai dapat menjadi agen proteksi sehingga berdampak pada menurunnya nilai kecernaan bahan kering dan bahan organik pada pencernaan rumen.

Pembuatan sabun kalsium (CaSoap) ini dilakukan melalui proses kimiawi yaitu dengan mereaksikan bahan lemak dengan larutan $\mathrm{NaOH}$ yang dikenal dengan proses saponifikasi (penyabunan). Setelah itu direaksikan lagi dengan larutan $\mathrm{CaCl}$ supaya diperoleh sabun kalsium yang bersifat tidak larut dalam air

Sabun kalsium merupakan bentuk lemak terlindung dan merupakan sumber lemak yang efektif dalam bahan pakan ternak ruminansia, karena sistem fermentasi rumen tetap normal, kecernaan asam lemaknya tinggi, dan sabun ini dapat dengan mudah dicampur pada beberapa jenis bahan pakan (Jenkins dan Palmquist, 1984). Lebih lanjut Jenkins and Lundy (2002), menyatakan bahwa ikatan yang terbentuk antara asam lemak dan garam kalsium pada sabun kalsium memiliki sifat yang stabil 
Tabel 3. Kecernaan bahan kering (KcBK) in vitro (\% BK)

\begin{tabular}{cccc}
\hline \hline Titik Inkubasi & Bungkil kedelai & Sabun kalsium & Pangola \\
\hline 2 & $44,29^{\mathrm{c}}$ & $38,65^{\mathrm{b}}$ & $15,46^{\mathrm{a}}$ \\
4 & $45,68^{\mathrm{b}}$ & $40,00^{\mathrm{b}}$ & $18,08^{\mathrm{a}}$ \\
8 & $48,42^{\mathrm{c}}$ & $42,66^{\mathrm{b}}$ & $22,28^{\mathrm{a}}$ \\
12 & $63,94^{\mathrm{c}}$ & $46,32^{\mathrm{b}}$ & $30,80^{\mathrm{a}}$ \\
24 & $70,62^{\mathrm{c}}$ & $54,40^{\mathrm{b}}$ & $43,06^{\mathrm{a}}$ \\
48 & $84,60^{\mathrm{c}}$ & $51,40^{\mathrm{a}}$ & $60,73^{\mathrm{b}}$ \\
\hline a, b, c superskrip yang berbeda pada baris yang sama menunjukkan perbedaan yang sangat \\
nyata (P<0,01).
\end{tabular}

Tabel 4. Kecernaan bahan organik (KcBO) tahap satu in vitro (\% BK)

\begin{tabular}{cccc}
\hline Titik Inkubasi & Bungkil kedelai & Sabun kalsium & Pangola \\
\hline 2 & $43,21^{\mathrm{c}}$ & $39,44^{\mathrm{b}}$ & $15,34^{\mathrm{a}}$ \\
4 & $45,03^{\mathrm{b}}$ & $41,27^{\mathrm{b}}$ & $17,75^{\mathrm{a}}$ \\
8 & $47,82^{\mathrm{c}}$ & $44,31^{\mathrm{b}}$ & $21,34^{\mathrm{a}}$ \\
12 & $65,67^{\mathrm{c}}$ & $46,32^{\mathrm{b}}$ & $30,96^{\mathrm{a}}$ \\
24 & $73,83^{\mathrm{c}}$ & $56,62^{\mathrm{b}}$ & $44,83^{\mathrm{a}}$ \\
48 & $85,82^{\mathrm{c}}$ & $52,50^{\mathrm{a}}$ & $61,02^{\mathrm{b}}$ \\
\hline
\end{tabular}
$(\mathrm{P}<0,01)$.

Tabel 5. Kecernaan bahan kering dan bahan organik sabun kalsium tahap II

\begin{tabular}{|c|c|c|c|}
\hline Kecernaan & Bungkil kedelai & Sabun kalsium & Pangola \\
\hline $\mathrm{KcBK}$ & $92,81^{\mathrm{c}}$ & $74,85^{\mathrm{b}}$ & $63,65^{\mathrm{a}}$ \\
\hline $\mathrm{KcBO}$ & $91,01^{\mathrm{c}}$ & $72,94^{\mathrm{b}}$ & $65,52^{\mathrm{a}}$ \\
\hline
\end{tabular}

pada $\mathrm{pH}$ netral sehingga tidak mudah mengalami hidrogenasi oleh mikrobia rumen. Akibatnya akan menurunkan nilai kecernaaan bahan kering dan bahan organik pada rumen.

Proses penyabunan mengakibatkan asam lemak bergabung dengan garam alkali membentuk sabun. Sabun yang terbentuk ini memiliki ekor hydrophobic dan hydrophilic. Ekor hydrophobic yang menyebabkan molekul sabun terlindung dari air (Fessenden dan Fessenden, 1986). Hal ini menyebabkan enzim mikroorganisme rumen tidak bisa mencerna bahan pakan yang diproteksi karena media reaksinya berupa air, sehingga mengakibatkan penurunan nilai kecernaan bahan kering dan bahan organik di dalam rumen.

\section{Kecernaan bahan kering dan bahan organik tahap dua (pasca rumen)}

Hasil kecernaan bahan kering $(\mathrm{KcBK})$ dan kecernaan bahan organik (KcBO) pakan suplemen sabun kalsium pasca rumen (tahap 2) secara in vitro disajikan pada Tabel 5.

Kecernaan Bahan kering (KcBK) dan kecernaan bahan organik (KcBO) sabun kalsium berpengaruh sangat nyata $(\mathrm{P}<0,01)$ terhadap kecernaan bahan kering (KcBK) dan kecernaan bahan organik (KcBO) bungkil kedelai dan rumput pangola. Hal ini dimungkinkan karena adanya perbedaan kandungan nutrien dari ketiga bahan tersebut. Sebagaimana pendapat Cheeke 
Tabel 6. Rerata nilai derajat keasaman $(\mathrm{pH})$ pada tahap I

\begin{tabular}{cccc}
\hline \hline Titik inkubasi & Bungkil kedelai & Sabun kalsium & Pangola \\
\hline 2 & 7,04 & 7,09 & 7,26 \\
4 & 7,03 & 7,20 & 7,19 \\
8 & 6,99 & 7,05 & 7,26 \\
12 & 7,14 & 7,04 & 7,02 \\
24 & 7,04 & 7,04 & 6,99 \\
48 & 7,06 & 7,14 & 6,88 \\
\hline
\end{tabular}

${ }^{\text {ns }}$ Tidak berbeda nyata $(\mathrm{P}>0,05)$ pada baris dan kolom yang sama

Tabel 7. Rerata nilai $\mathrm{pH}$ pada tahap II

\begin{tabular}{lccc}
\hline \hline Variabel & Bungkil kedelai & Sabun kalsium & Pangola \\
\hline $\mathrm{pH}$ & 1,03 & 1,03 & 0,99 \\
\hline ns & Tidak berbeda nyata $(\mathrm{P}>0,05)$ pada baris dan kolom & yang sama &
\end{tabular}

(2005), menyatakan bahwa kandungan nutrien bahan pakan seperti tingginya kandungan lemak akan berpengaruh menurunkan kecernaan asam lemak total yang masuk ke dalam usus halus ternak.

Hasil penelitian di atas menunjukkan bahwa mekanisme proteksi rumen terhadap sabun kalsium tidak didasarkan pada titik cair asam lemak akan tetapi berdasarkan pada level keasaman atau $\mathrm{pH}$ rumen dan usus halus. Sabun kalsium akan tetap utuh pada lingkungan netral, $\mathrm{pH} 7$ misalnya, tetapi akan terurai dalam lingkungan asam, pH 3 misalnya (Fernandez, 1999). Normalnya $\mathrm{pH}$ rumen 6,5 - 6,8 dimana keutuhan akan sabun kalsium ini tetap terjaga. Sabun kalsium ini akan lolos dari proses biohidrogenasi oleh mikrobia rumen, tidak mengganggu aktivitas rumen yang normal dan langsung melewati rumen. Sedangkan di daerah abomasum, sabun kalsium berada pada suatu lingkungan asam, pH 2 - 3, sehingga secara langsung sabun kalsium akan terurai dalam bentuk kalsium dan asam lemak. Pada saat ini asam lemak akan terbebas, mudah dipecah dan diserap oleh tubuh.

Schaefer (2000), menyatakan bahwa ikatan pada sabun kalsium bersifat riversibel (dapat lepas kembali) pada kondisi asam. Sabun yang dihasilkan bersifat stabil (tidak mudah mencair atau terurai) dalam cairan rumen yang mempunyai $\mathrm{pH}$ netral, namun ikatan $\mathrm{Ca}$ dan asam lemak pada saat melewati abomasum yang mempunyai $\mathrm{pH}$ sangat asam akan lepas menghasilan ion $\mathrm{Ca}$ dan asam lemak bebas dan selanjutnya masuk usus halus dan diserap pada usus halus. Pada saat masuk usus besar yang mempunyai $\mathrm{pH}$ netral sisa ion $\mathrm{Ca}$ dan asam lemak tidak membentuk sabun kembali.

\section{Derajat keasaman $(\mathrm{pH})$ rumen}

Rerata nilai derajat keasaman $(\mathrm{pH})$ pada sistem pencernaan tahap I (rumen) dalam penelitian ini disajikan dalam Tabel 6 .

Hasil penelitian menunjukkan bahwa nilai $\mathrm{pH}$ pada tahap I antar perlakuan dan titik inkubasi tidak berbeda nyata (Tabel 6). Hal ini menunjukkan bahwa sabun kalsium tidak memengaruhi nilai $\mathrm{pH}$ rumen, sehingga tidak mengganggu ekosistem dalam rumen. Hal ini selaras dengan penelitian Kowalski (1997) yang menyatakan bahwa penambahan sabun kalsium minyak kanola bersifat inert dalam rumen sehingga tidak mengubah $\mathrm{pH}$ rumen. Sebagaimana Ferlay et al. (1993) menyatakan bahwa sabun kalsium bersifat inert di dalam rumen, tidak beracun bagi bakteri rumen, dan tidak berdampak negatif pada pencernaan rumen.

Owens dan Zinn (1988) menyatakan bahwa kisaran $\mathrm{pH}$ normal untuk aktivitas 
mikrobia rumen dalam mendegradasi pakan dan berlangsungnya proses fermentasi adalah 5,5 sampai 7,6. Hasil penelitian menunjukkan bahwa nilai $\mathrm{pH}$ berdasarkan titik inkubasi dan perlakuan berkisar antara 7,01 sampai 7,12, sehingga nilai $\mathrm{pH}$ tersebut berada dalam kisaran normal. Bila mikrobia rumen berada pada kondisi $\mathrm{pH}$ yang sesuai maka proses pertumbuhan dan metabolisme mikrobia tidak akan terganggu sehingga aktivitas mikrobia berjalan dengan normal dan proses pencernaan bahan pakan akan optimal (Prawirokusumo, 1994). Rerata nilai pH pada tahap II disajikan dalam Tabel 7.

Hasil penelitian menunjukkan bahwa nilai $\mathrm{pH}$ pada tahap II antar perlakuan tidak berbeda nyata $(\mathrm{P}>0,05)$ (Tabel 7). Hal ini menunjukkan bahwa sabun kalsium tidak memengaruhi nilai $\mathrm{pH}$ pada abomasum. Jenkins and Palmquist (1984) menyatakan bahwa sabun kalsium akan terpisah secara sempurna pada kondisi asam abomasum. Sabun kalsium dapat digunakan dengan baik oleh ruminansia, $\mathrm{pH}$ ingesta saat keluar dari abomasum sangat rendah dan tetap rendah saat mendekati usus halus karena keterbatasan aktivitas buffer pankreas pada ruminansia. $\mathrm{pH}$ yang rendah menyebabkan pemisahan sabun kalsium, sehingga memungkinkan terjadinya penyerapan asam lemak (Cheeke, 2005).

\section{SIMPULAN}

Pakan suplemen sabun kalsium cukup efektif/lebih tahan dari degradasi mikrobia di dalam rumen dari pada pakan tanpa perlakuan proteksi, kondisi $\mathrm{pH}$ cairan rumen menunjukkan kisaran $\mathrm{pH}$ yang optimal sehingga tidak mengganggu fermentasi dalam rumen serta sabun kalsium dapat terdegradasi dan tercerna di dalam abomasum sampai dengan usus halus.

\section{UCAPAN TERIMAKASIH}

Penulis mengucapkan terimakasih kepada Direktorat Jenderal Pendidikan Tinggi, Kementrian Pendidikan dan Kebudayaan Republik Indonesia dan
Lembaga Penelitian dan Pengabdian Kepada Masyarakat Universitas Sebelas Maret yang telah memberikan dana penelitian Hibah Bersaing Tahap I BOPTN, sehingga penelitian ini dapat terlaksana dengan baik.

\section{DAFTAR PUSTAKA}

Agus, A. 2012. Bahan Pakan Konsentrat Untuk Sapi. Citra Aji Parama, Yogyakarta.

Aharoni, Y., A. Orlov and A. Brosh. 2004. Effect of high-forage content and olseed supplementation of fattening diets on conjugated linoleic acid (CLA) and trans fatty acids profiles of beef lipid fractions. J. Anim._Sci. and Techno. 117: 43-60.

Ashes, J.R., E. Fleck and T. W. Scott. 1995. Dietary manipulation of membrane lipids and its implications for their role in the production of second messenger. In: W.V. Engerhardt, S.L. Marek, G. Breves and D. Giesecke. (eds): Ruminant Physiology: Digestion, Metabolism, Growth and Reproduction. Ferdinand Enke Verlag. Stuttgart. pp : 373-385.

Astuti, M. 2007. Diktat praktikum rancangan percobaan bidang peternakan (PTO 6001). Laboratorium Pemuliaan Ternak. Fakultas Peternakan Universitas Gadjah Mada. Halaman: 17-19.

Cheeke, P. R. 2005. Applied Animal Nutrition: Feed and Feeding $3^{\text {rd }}$ Edition. Pearson Prentice Hall, New Jersey.

Elliot, J.P., J.K. Drackley, C.G. Aldrich and N.R. Merchen. 1997. Effect of saturation and esterification of fat sources on site and extent of digestion in steers: ruminal fermentation and digestion of organik matter, fiber and nitrogen. J. Anim. Sci. 75: 2803-2813.

Ferlay, A., J. Charbot, Y. Elmeddah, and M. Doreau. 1993. Ruminal lipid balance and intestinal digestion by dairy cows fed calcuim salts of rapeseed oil fatty acids or rapeseed oil. J. Anim. Sci. 71: 2237 - 2245.

Fernandez, J.L. 1999. Rumen by-pass fat for dairy diets: when to use which type. Feed International. Agust. P: 18-21.

Fessenden, R. J. and J. S. Fessenden. 1986. Kimia organik. Erlangga, Jakarta.

Jenkins, T.C., and F. Lundy. 2002. Feeding various fat sources to lactating dairy 
cows and their effect on milk quality. http://www.das.psu.edu/researchextension/dairy/nutrition/pdf/jenkins-fatsources-and-effects-on-milk-quality2001.pdf.

Jenkins, T.C. dan D.L. Palmquist. 1984. Effect of Fatty Acid or Calcium Soaps on Rumen and Total Nutrient Digestibility of Dairy Rations. J. Dairy Sci. 67: 978-986.

Johnson, K.A., R.L. Kincald, H.H. Westberg, C.T. Gaskins, B.K. Lamb, and J.D. Conrath. 2002. The effect of oilseed in diets of lactating cows on milk production and methane emissions. J. Dairy Sci. 85: 1509-1515.

Kamal, M. 1998. Bahan Pakan Dan Ransum Ternak. Laboratorium Makanan Ternak Jurusan Nutrisi dan Makanan ternak. Fakultas Peternakan. UGM. Yogyakarta.

Kowalski, Z. M. 1997. Rumen fermentation, nutrient flow to the duodenum, and digestibility in bulls fed calcium soaps of rapeseed fatty acids and soya bean meal coated with calcium soaps. Anim. Feed sci. Technol. 69: 298 - 303.

Lanyasunya, T.P., H.H. Musa, Z.P. Yang, D.M. Mekki and E.A. Mukisara. 2005. Effects of poor nutrition on reproduction of dairy stock on smallholder farms in the tropics. Pakistan Journal of Nutrition, 4 (2): 117122.

Owens, F. N. and R. Zinn. 1988. Protein Metabolism of Ruminant Animal Digestive Physiology and Nutrition. Reston Boook Prentice Hall, Englewood Cliffs, New Jersey.

Pramono, A., Kustono., P. P. Putro., D.T.Widayati., dan H.Hartadi. 2011.
Stability of sardine fish oil and hydrolyzed blood protected to increase productivity of dairy cows. Prociding International seminar "Advanced Technology on Veterinary and Veterinary and Life Sciences" March 12, 2011. Yogyakarta. Indonesia. ISBN: 979-979-96104-4-7.

Prawirokusumo, S. 1994. Ilmu Gizi Komparatif. BPFE Yogyakarta. Yogyakarta.

Putro, P.P. 2007. Pengaruh defisiensi nutrisi pada reproduksi sapi betina. Apresiasi Peternakan Sapi Potong, Dinas Pertanian DIY. Yogyakarta.

Rusmana, D., 2000. Pengaruh suplementasi minyak ikan, minyak jagung dan $\mathrm{ZnCO}_{3}$, dalam ransum terhadap kandungan " $\hat{\omega}-3$, ஸे-6 PUFA" dan kolesterol telur dan karkas ayam kampung. Tesis. Program Pascasarjana, Institut Pertanian Bogor. Bogor

Schaefer, D.M. 2000. Potential for Altering Quality of Muscle and Milk from Ruminants: Antioxidants In Muscle. Wiley Interscience, New York.

Tilley, J. M. A. and R. A. Terry. 1963. A two stage technique for in vitro digestion of forage crops. J. British Grassland Society. 18: 104 - 111.

Ueda. K, A. Ferlay, J. Chabrot, J. J. Loor, Y. Chilliard, and M. Doreau. 2003. Effect of linseed oil supplementation on ruminal digestion in dairy cows fed diets with different forage:concentrate ratios. J. Dairy Sci. 86:3999-4007

Utomo, R. 2010. Modifikasi metode penetapan kecernaan in vitro bahan kering atau bahan organik. Sintesis. 5: 1 - 11 . 